From Knowledge to Wisdom

\title{
Journal of Traffic and Transportation Engineering
}

Volume 5, Number 5, Sep.-Oct. 2017

\%

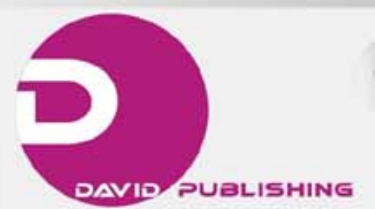

*

* 


\section{Journal of Traffic and}

\section{Transportation Engineering}

Volume 5, Number 5, Sep.-Oct. 2017 (Serial Number 19)

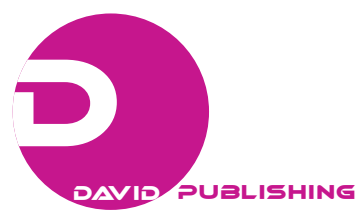

David Publishing Company

www.davidpublisher.com 


\section{Publication Information:}

Journal of Traffic and Transportation Engineering is published bimonthly both in hard copy and online (ISSN 2328-2142) by David Publishing Company located at 616 Corporate Way, Suite 2-4876, Valley Cottage, NY 10989, USA.

\section{Aims and Scope:}

Journal of Traffic and Transportation Engineering, a bimonthly professional academic journal, covers all sorts of researches on transports, logistics, railway engineering, road engineering, port and coastal engineering and waterway engineering, engineering management, information management, etc., as well as other issues.

\section{Editorial Board Members:}

Prof. Alexander Medvedev (USA), Prof. Zdenek Dvorak (Slovakia), Prof. Hui Xie (China), Assoc. Prof. Dragan Simić (Serbia), Prof. Luís Manuel Braga da Costa Campos (Croatia), Dr. Francesca Pagliara (Italy), Dr. Judith L. Mwakalonge (USA), Assoc.Prof. Galina Ivanova Zamfirova (Bulgaria), Assoc. Prof. Ozgur Baskan (Turkey), Assoc. Prof. Jasmina Pasagic Skrinjar (Croatia), Dr. Marijan Rajsman (Croatia), Dr. Darko Babic (Croatia), Assoc. Prof. Ljupko Šimunović (Bosnia and Herzegovina), Dr. Edouard Ivanjko (Croatia), Prof. Nobuyo Kasuga (Japan), Prof. Rosa Maria Padroni (Brazil), Prof. Bin Jia (China), Prof. Francisco Gildemir Ferreira da Silva (USA), Prof. Zaili Yang (UK).

Manuscripts can be submitted via Web Submission, or e-mailed to traffic@davidpublishing.com or JTTE_davidpublishing@yahoo.com. Submission guidelines and Web Submission System are available at http://www.davidpublisher.com.

\section{Editorial Office:}

616 Corporate Way, Suite 2-4876, Valley Cottage, NY 10989, USA

Tel: 1-323-984-7526, 323-410-1082 Fax: 1-323-984-7374, 323-908-0457

E-mail: traffic@davidpublishing.com,JTTE_davidpublishing@yahoo.com

Copyright@2017 by David Publishing Company and individual contributors. All rights reserved. David Publishing Company holds the exclusive copyright of all the contents of this journal. In accordance with the international convention, no part of this journal may be reproduced or transmitted by any media or publishing organs (including various websites) without the written permission of the copyright holder. Otherwise, any conduct would be considered as the violation of the copyright. The contents of this journal are available for any citation. However, all the citations should be clearly indicated with the title of this journal, serial number and the name of the author.

\section{Abstracted/Indexed in:}

Google Scholar

Chinese Database of CEPS, American Federal Computer Library center (OCLC), USA

Chinese Scientific Journals Database, VIP Corporation, Chongqing, P. R. China

Ulrich's Periodicals Directory

ProQuest/CSA Social Science Collection, Public Affairs Information Service (PAIS), USA

Summon Serials Solutions

China National Knowledge Infrastructure (CNKI)

Academic Keys

CiteFactor, USA

SJournal Index

Scientific Indexing Services

\section{Subscription Information:}

\$360/year (print)

\section{David Publishing Company}

616 Corporate Way, Suite 2-4876, Valley Cottage, NY 10989, USA

Tel: 1-323-984-7526, 323-410-1082 Fax: 1-323-984-7374, 323-908-0457

E-mail: order@davidpublishing.com

Digital Cooperative Company: www.bookan.com.cn

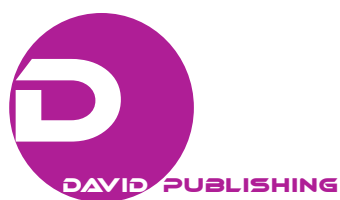




\section{Journal of Traffic and Transportation Engineering}

Volume 5, Number 5, Sep.-Oct. 2017 (Serial Number 19)

\section{Contents}

237 Aerodynamics Loads on a Heeled Ship

Romain Luquet, Pierre Vonier, Jean-Francois Leguen and Andrew Prior

246 Optimization of the Mix-Design System for the Sub-ballast Railroad

Martínez Soto Fernando and Di Mino Gaetano

260 Passenger Choice Behavior between Direct and Transit Flights-A Case Study on Passengers Using Hub Airports in the Northeast Asian Region

Se-Yeon Jung, Baek-Jae Kim and Kwang-Eui Yoo

271 Tangible Assets Threats and Hazards: Risk Assessment and Management in the Port Domain

Constantinos I. Chlomoudis, Petros L. Pallis and Ernestos S. Tzannatos

279 A Business Ecosystem's Model for Harnessing Nigeria's Ocean Economy

Chinedum Onyemechi, Theophilus Chinonyerem Nwokedi, Okechukwu Okeke, Chinemerem Igboanusi, Chigozie Uzoma Odumodu and David Chikwendu 


\title{
Optimization of the Mix-Design System for the
}

\section{Sub-ballast Railroad}

\author{
Martínez Soto Fernando ${ }^{1}$ and Di Mino Gaetano, ${ }^{1,2}$ \\ 1. Department of Civil, Environmental and Materials Engineering (DICAM), University of Palermo, 90128 Palermo, Italy; \\ 2. Department of Civil, Environmental, Aerospace, Materials Engineering (DICAM), University of Palermo, 90128 Palermo, Italy
}

\begin{abstract}
Bituminous sub-ballast is an alternative solution to the unbound granular sub-ballast used in the railway track due to several benefits that it can provide. Indeed, it contributes to maintain the moisture content in the subgrade unchanged during all year. This decreases the subgrade deterioration process. Moreover, the presence of bituminous sub-ballast can also reduce vertical stiffness variations on the track; it can have a positive effect in the maintenance needs at transition sections (bridge-embankment) and in the attenuation of the vibrations induced by the rail traffic. Despite the importance of the presence of the bituminous sub-ballast to conceive the construction and/or rehabilitation of sustainable infrastructure, in literature, there are only fragmentary information regarding the definition of benchmark criteria for their mix design. The superpave mix design approach used in road domain is applied systematically in the railway domain, without being adjusted for different load configuration of the rail track system. This research work aims at defining the benchmark criteria for the bituminous sub-ballast mix design to reduce the approximations involved in the recipe optimization due to the limitation of applying the superpave system in the railway domain. The methodology proposed aims at selecting the RESAL (rail equivalent single axle load) and therefore, transforming the entire traffic spectrum on the track lines in number of ESALs. Afterwards, the $N_{\text {design }}$ has been calculated as function of the rail traffic level. Finally, a case study of bituminous sub-ballast mix design has been investigated for a first verification of the methodology proposed.
\end{abstract}

Key words: Sub-ballast, superpave, railway, bituminous layer, ESAL, $N_{\text {design }}$.

\section{Introduction}

\subsection{Bituminous Sub-ballast}

Sub-ballast is a layer, of usually $12-15 \mathrm{~cm}$ thickness, interposed between the ballast and the blanket. The blanket is a layer, or several layers, of granular material laid over the subgrade to conform to the formation and create its desired properties (Fig. 1). Frequently, unbound granular materials are replaced by bituminous sub-ballast that may provide additional benefits to the subgrade protection and track performance.

For instance, the bituminous sub-ballast, being almost completely water-resistant, protects the subgrade from the seasonal variations of moisture and atmospheric actions. This has an important effect in

Corresponding author: Fernando Martínez Soto, Ph.D.; research fields: asphalt materials, transports, construction, civil engineering, architecture, and environmental sustainability. E-mail: arquinandoms@gmail.com. slowing down the deterioration process over the track's service life [1]. Indeed, the sub-ballast's role in reducing the seasonal amplitude of vertical displacements during its lifetime decreases the maintenance interventions, not only in the smooth parts of the track lines [2] but also in the transition sections (bridge-embankment) [3]. Moreover, the bituminous sub-ballast plays an important role in distributing the load and reducing the solicitations on the subgrade. Indeed, it dissipates the stress transmitted by passing trains, ensuring a higher protection of the formation compared to a granular sub-ballast [4].

The bituminous sub-ballast is also preferable to cement bound sub-ballast. In fact, asphalt concrete does not need an anti-evaporation protection and it can be covered with other layers after only a few hours rather than waiting for days. Moreover, it reduces the sub-ballast thickness and therefore the use of aggregates. Nevertheless, it is important to consider the 
effect of the temperature on the mechanical properties of the bituminous sub-ballast which can significantly affect its service life. May be necessary to investigate its applicability in certain areas because the resistance to plastic deformation decreases significantly at high temperatures [4].

Recent studies $[5,6]$ have highlighted the capability of bituminous sub-ballast to improve the attenuation of vibrations induced by rail traffic, especially when crumb rubber is added to the mixture.

Considering all the above-mentioned aspects, the use of bituminous sub-ballasts could improve the track quality and durability (higher protection of the subgrade in term of dissipation of loads and water infiltration). This leads to reduce maintenance interventions and associated track closures; improving adherence to track geometric parameters [7].

\subsection{Mix Design Optimization of Bituminous Mixtures}

The importance of the asphalt layer for the quality and durability of the track imposes a reflection on the mix design and the fabrication process of this material to ensure its structural and functional roles. The bituminous sub-ballast is composed of a dense-graded bituminous mixture with a maximum aggregate size of 22-25 mm [7] similarly to the base course for road pavements. Whereas, the quantity of bitumen in the sub-ballast is normally increased of $0.5 \%$ compared to the base course and the air voids decreased to $1 \%-3 \%$ to avoid the permeability of the layer [8]. This result in a mixture characterized by a medium permanent deformation resistance. However, rutting does not represent a main concern in the track-bed because the presence of ballast allows applying the pressures of axle loads over a wider area.

Bleeding and flushing does not represent either a problem because the wheels do not come into direct contact with the asphalt layer and extreme temperatures are minimized at the depth of the track-bed [8]. Despite the composition of the sub-ballast layer being similar to the one of the base course used in road pavement, the configuration of the system in terms of solicitations and temperature profile is different. For this reason, different mix design systems and approaches should be adopted for the optimization of the asphalt mixtures when used in the railway domains.

In recent years, several research efforts have been employed to investigate and refine the Superpave mix design system of HMA (hot mix asphalt) for new construction. In predicting performance for multilayer, specific ground rules govern the treatment of the main layer distresses: permanent deformation, fatigue and low-temperature cracking.

The objective of the Superpave mix design system applied to the HMA for roads is to define a blend of bitumen and aggregates that yields a paving mix with certain characteristics such as sufficient voids in the mineral aggregate (VMA), and air voids $\left(\mathrm{V}_{\mathrm{a}}\right)$, satisfactory workability, and performance over the entire service life of the pavement [9].

These specifications should be combined to provide a framework of checks and balances to ensure that the resulting asphalt mixture is durable and rut resistant

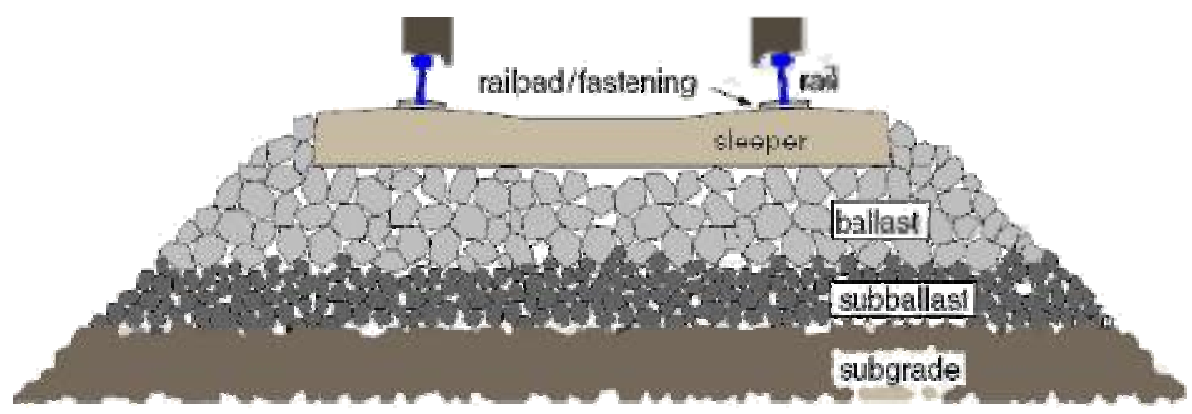

Fig. 1 Section through railway track showing the sub-ballast and formation layers. 


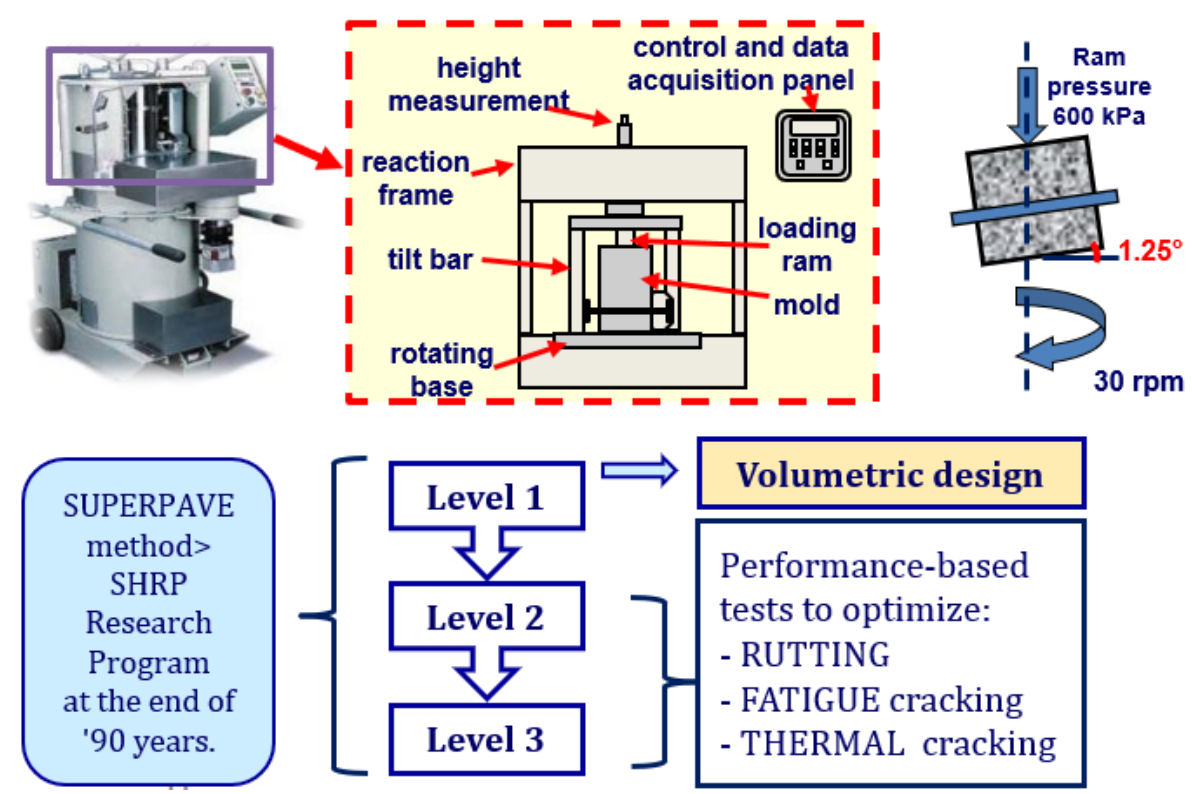

Fig. 2 Structure of the Superpave mix design system.

[10]. For this purpose, the Superpave gyratory compactor establishes three different gyration numbers: $N_{\text {initial }}, N_{\text {design }}$ and $N_{\max } . N_{\text {design }}$ is the design number of gyrations required to match the density of the material expected in the field and it is the parameter considered in this study (Fig. 2).

The original table of Superpave envisaged different design gyration levels that represent seven traffic levels for each of four climates [9]. Traffic levels are defined by intervals counting the number of passages of ESALs (equivalent single axle loads) accumulated during a 20 -year design life. Different climates were expressed by the average 7-day high air temperature recorded at the project site. $N_{\text {design }}$ increased as design ESALs and high air temperature increased. In the years following the improved $N_{\text {design }}$ value, the climatic region factors were eliminated and incorporated in the bitumen selection process depending on the performance grade (PG).

Table 1 shows the compaction parameters to be set up when using Superpave gyratory compactor [11].

However, in literature, there is only fragmentary information regarding the definition of benchmark parameters for the mix design of bituminous sub-ballast.

\section{Problem Statement and Objectives}

Table 1 indicates the number of gyrations needed to obtain the in-place pavement density at the design traffic levels in the road domain. Nevertheless, to use these parameters in the railway domain, it is first necessary to determine the corresponding RESAL (rail equivalent single axle load), calculating the compression stress at the bottom of the base layer and transform the entire spectrum of traffic into the number of passages of RESALs.

This paper aims at presenting a methodology to adapt the Superpave mix design approach to the railway system defining the RESAL and transforming the entire traffic spectra on the track lines of interest into number of RESALs. Afterwards, the $N_{\text {design }}$ has been calculated as function of traffic. Indeed, the definition of a regression function of $N_{\text {design }}$ allows assigning a specific number of gyrations for each number

Table 1 Compaction parameters for Superpave gyratory compactor.

\begin{tabular}{llll}
\hline Design ESALs $\left(10^{6}\right)$ & $N_{\text {initial }}$ & $N_{\text {design }}$ & $N_{\max }$ \\
\hline$<0.3$ & 6 & 50 & 75 \\
0.3 to $<3$ & 7 & 75 & 115 \\
3 to $<30$ & 8 & 100 & 160 \\
$\geq 30$ & 9 & 125 & 205 \\
\hline
\end{tabular}


of RESALs. Finally, a case study has been investigated to verify the proposed methodology.

\section{Methodology}

The proposed methodology is composed of different stages:

(1) compare the solicitations induced in the sub-ballast layer with the ones produced on the road base course;

(2) define the RESAL, i.e., the rail axle load that produces the same vertical displacement $(w)$ at high temperatures and the same horizontal tensile strain $\left(\varepsilon_{t}\right)$ at low temperatures produced by the ESAL in the road structure;

(3) convert the entire traffic spectrum into number of RESALs;

(4) define $N_{\text {design }}$ as function of traffic level;

(5) case study of mix design optimization of bituminous sub-ballast.

\subsection{RESALs}

To determine the RESAL, two reference sections, one for road and one for railway, have been selected. The stress-strain behaviour in both sections at the bottom of the base course and sub-ballast were defined performing several simulations using $\mathrm{KENPAVE}^{\circledR}$ and KENTRACK $^{\circledR}$ software, respectively. The two sections (types and thicknesses of layers) and the points where the solicitations were calculated are shown in Fig. 3.

$\mathrm{KENPAVE}^{\circledR}$ is a software that calculates stresses, strains and deformations in flexible and rigid pavements [12]. KENTRACK ${ }^{\circledR}$ is the corresponding software used for the analysis and design of railway track-beds. By applying the Burmister's layered theory and the finite element method in the KENTRACK ${ }^{\circledR}$ program, the stresses, strains and deformations can be calculated in every point of the track-bed [13].

In the case of track-beds containing a bituminous sub-ballast layer, the calculated compressive stresses at high temperatures could be indicative of potential long-term track-bed settlement failure. The tensile strains at the bottom of the asphalt layer, may be indicative of potential fatigue cracking at low temperatures, too [14].

Fatigue cracking at low temperatures and rutting at high temperatures are two of the most common causes of asphalt failure in flexible pavements. For this reason, in the framework of this work, the RESAL has been defined as the rail axle load that produces the same vertical displacement $(w)$ at high temperatures and the same horizontal tensile strain $\left(\varepsilon_{t}\right)$ at low temperatures produced by the ESAL $(80 \mathrm{kN})$ in the road structure. In order to find the RESAL that produces the same solicitations of the road ESAL, several simulations were run using $\mathrm{KENTRACK}^{\circledR}$ and $\mathrm{KENPAVE}^{\circledR}$.

The vehicle considered in this study was a high-speed train operating for the regular Italian rail lines. Load train consists of $160 \mathrm{kN}$ in two wheels on each side, spaced at $60 \mathrm{~cm}$ on centers. The loading system of the FEM model implemented in Kentrack was designed considering the Minuetto Ale501/502-Le220 (Italian) train configuration, composed of 4 bogies (16 axles) with a static load of 16 tons per axle and a distance between axles (wavelength of vibration) of $14.65 \mathrm{~m}$. The running speed is between $160-250 \mathrm{~km} / \mathrm{h}(56-70 \mathrm{~m} / \mathrm{s})$, diesel-electric power and $1,435 \mathrm{~mm}$ standard gauge. The dimensions are 52・2.95•3.80 m (Fig. 4).

On the high-speed rail line, there is a track type RFI-260, mass $>350 \mathrm{~kg}$, thickness $30 \mathrm{~cm}$, a length of $2.60 \mathrm{~m}$ and an Elastic modulus of 50GPa, according to the Specifications "RFI TCAR.SP.AR.03-002 Rev.A of 25/02/2003" [22], with connecting elements with an indirect rail-cross connection, direct mounting and elastic deformability for high-speed. The crossbars have a separation of $60 \mathrm{~cm}$.

Therefore, the sections in the detected type of the railway platform are current underlayment system. The tracking platform of $13.10 \mathrm{~m}$ wide, with a double 


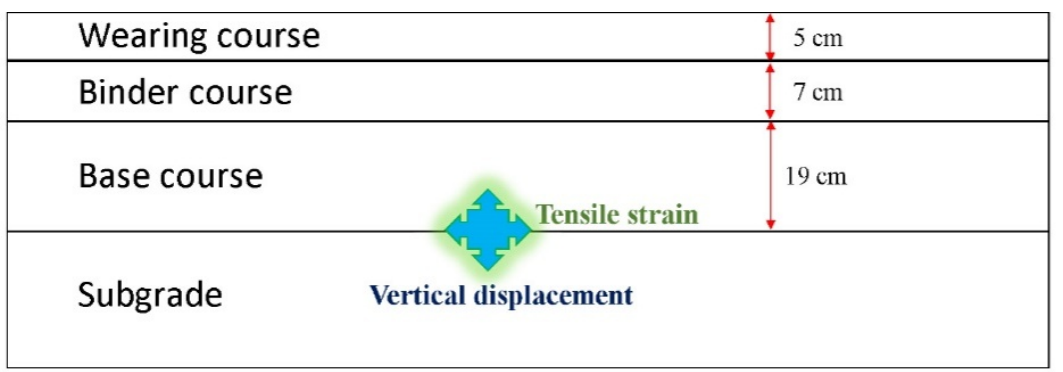

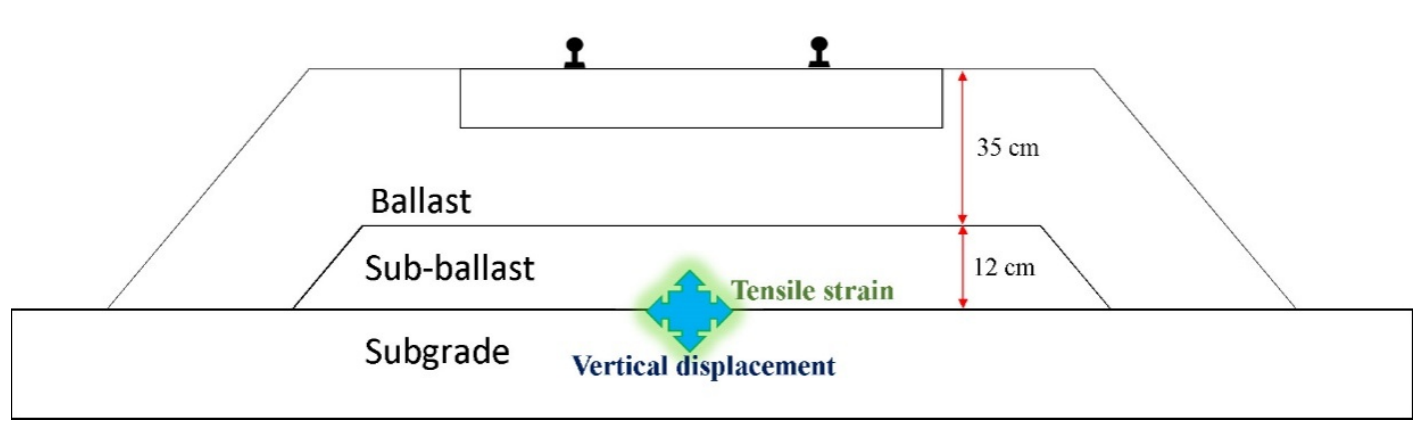

Fig. 3 Road and railway sections for simulations with $\operatorname{KENPAVE}^{\circledR}$ and $\operatorname{KENTRACK}^{\circledR}$.
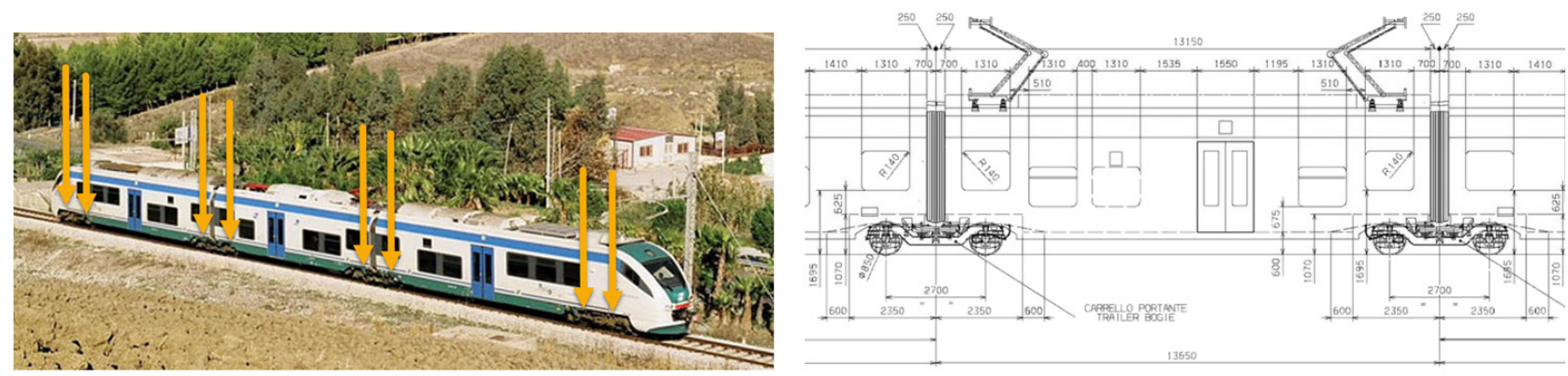

Fig. 4 Type of train considered for the rail simulations.

Table 2 Parameters selected for KENTRACK ${ }^{\circledR}$ simulations.

\begin{tabular}{|l|l|l|l|l|l|}
\hline \multicolumn{2}{|l|}{ Type of rail: 60E1 (UIC) 3141 } & \multicolumn{3}{|l|}{ Fastening system type: Pandrol fastclip } \\
\hline $\begin{array}{l}\text { Young's } \\
\text { modulus }[\mathrm{MPa}]\end{array}$ & $\begin{array}{l}\text { Limit of } \\
\text { proportionality }[\mathrm{MPa}]\end{array}$ & $\begin{array}{l}\text { Limit of elasticity } \\
{[\mathrm{MPa}]}\end{array}$ & $\begin{array}{l}\text { Static stiffness (Rubber } \\
\text { pad) }[\mathrm{MN} / \mathrm{m}]\end{array}$ & $\begin{array}{l}\text { Clamping force } \\
{[\mathrm{kN}]}\end{array}$ & Creep resistance $[\mathrm{kN}]$ \\
\hline 192,000 & 500 & 600 & $>150$ & $>16$ & $>9$ \\
\hline Sleepers in PSC (Portland slag cement) wires & $\begin{array}{l}\text { Sleeper unit } \\
\text { weight }[\mathrm{g} / \mathrm{cm}]\end{array}$ & Sleepers spacing $[\mathrm{cm}]$ & $\begin{array}{l}\text { Length of } \\
\text { sleeper }[\mathrm{cm}]\end{array}$ & $\begin{array}{l}\text { Center to center distance } \\
\text { between rails }[\mathrm{cm}]\end{array}$ \\
\hline $\begin{array}{l}\text { Sleeper thickness } \\
{[\mathrm{cm}]}\end{array}$ & Sleeper width $[\mathrm{cm}]$ & 60 & 259 & 143.5 \\
\hline 21 & 16.9 & 5.18 & Single & \\
\hline
\end{tabular}

Note: UIC = Union Internationale des Chemins de fer.

Table 3 Parameters selected for KENPAVE ${ }^{\circledR}$ simulations.

\begin{tabular}{|l|l|l|l|}
\hline Road structure & Type of responses & Number of periods & Number of layers \\
\hline Type of material & Displacement & 5 & 4 \\
\hline Linear & $\begin{array}{l}\text { CR_contact radius of } \\
\text { circular loaded areas [cm] }\end{array}$ & $\begin{array}{l}\text { CP-contact pressure on } \\
\text { circular loaded areas [psi] }\end{array}$ & $\begin{array}{l}\text { NR-number of radial coordinates to be } \\
\text { analyzed under a single wheel [-] }\end{array}$ \\
\hline Load information & 800 & 1 \\
\hline Type of load & 12.62 & \\
\hline Single axle with single tire &
\end{tabular}




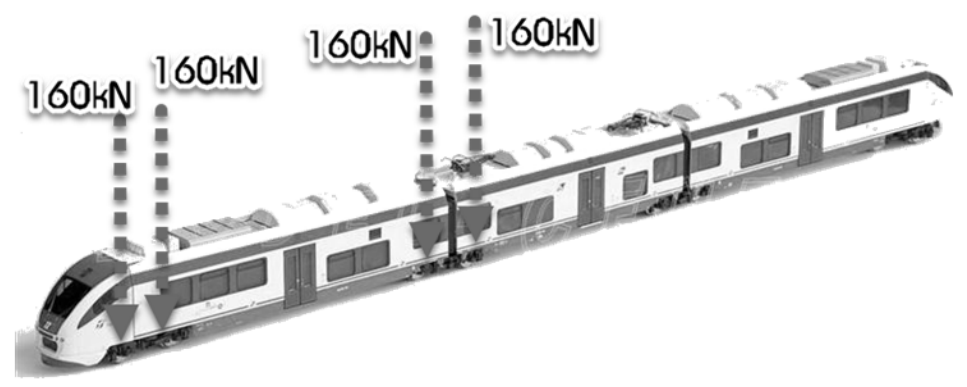

(a)

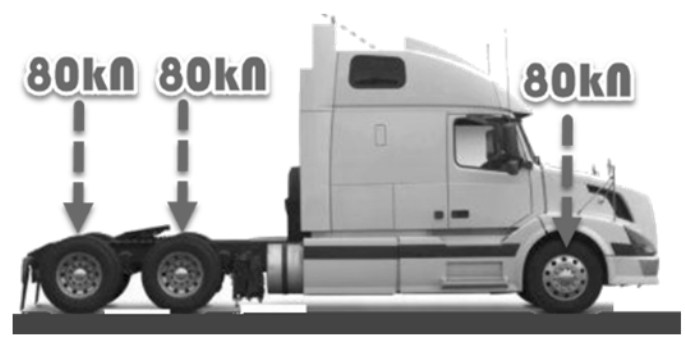

(b)

Fig. 5 Type of vehicle considered for the road simulations: (a) Convoy Aln 501- Ale Minuetto (train for simulations); (b) vehicle considered for road simulations.

track at a center distance of $4.50 \mathrm{~m}$, speed $250 \mathrm{~km} / \mathrm{h}$, crossbar type RFI 260, standard armament on ballast, and sub-ballast in a bituminous conglomerate of thickness $12 \mathrm{~cm}$ (Fig. 5).

For this purpose, it was necessary to define a complete set of information regarding all the components and the materials involved in the systems. The principal parameters (road-railway) used to create the reference sections are demonstrated in Tables 2 and 3.

The determination of the properties of the materials

$$
T_{\operatorname{pav}(z, t)}=T_{M}+R+\left(\frac{T_{V}}{2}+3 R\right) \cdot F \cdot e^{-C x} \cdot \sin \left(0.262 t-C_{x}-\operatorname{arctg}\left(\frac{C}{h c / K}\right)\right)
$$

where:

$T_{\operatorname{pav}(z, t)}=$ pavement temperature at the depth $z$ and time $t\left[{ }^{\circ} \mathrm{C}\right]$;

$T_{M}=$ mean effective air temperature $\left[0-35^{\circ} \mathrm{C}\right]$;

$T_{V}=$ maximum variation in temperature $\left[10.5^{\circ} \mathrm{C}\right]$;

$R=2 / 3(b \cdot I) / 24 h_{c}=$ contribution of the solar radiation $\left[8.35{ }^{\circ} \mathrm{C}\right]$;

$h_{c}=4.882 \cdot\left(1.3+0.4332 \cdot v^{3 / 4}\right)=$ surface coefficient based on the wind speed [24.25 kcal/hours $\left.\mathrm{m}^{2} \cdot{ }^{\circ} \mathrm{C}\right]$;

$v=$ wind speed $[17.25 \mathrm{~km} / \mathrm{h}]$;

$I=$ average radiation $\left[5.398 \mathrm{kcal} / \mathrm{m}^{2} \cdot\right.$ day $]$;

$b=$ absorptivity of surface to solar radiation [0.21];

$C=(0.131 \cdot \mathrm{s} \cdot \mathrm{w}) / \mathrm{K}\left[6.71\right.$ hour $\left.^{0.5} / \mathrm{m}\right]$;

$s=$ specific heat $\left[0.21 \mathrm{kcal} / \mathrm{kg}^{\circ} \mathrm{C}\right]$;

$\mathrm{w}=$ density $\left[2,500 \mathrm{~kg} / \mathrm{m}^{3}\right]$;

$K=$ thermal conductivity $\left[1.5 \mathrm{kcal} / \mathrm{mh}^{\circ} \mathrm{C}\right]$; and

$x=$ depth $[0.47 \mathrm{~m}]$.

In the framework of this paper, Eq. (1) was used to represents a fundamental step for the definition of the input data of the models, implemented by KENPAVE ${ }^{\circledR}$ and KENTRACK ${ }^{\circledR}$. In this overall framework, attention must be paid to the bituminous materials. They are characterized by thermal susceptibility; thus, it is necessary to know the temperature within the layer and the relationship with the mechanical characteristics.

Eq. (1) [15] expresses the temperature in the layer at the depth $z$ and at time $t$ :

determine the temperature in the road base course and in the sub-ballast layer considering the variations introduced by M. Crispino [16]. The principal difference between road and railway is in the absorptivity of the surface of the structure to solar radiation. For the surface layer in the road structure, the absorptivity is equal to 0.9 [15], in the case of railway, the coefficient of absorptivity of ballast has been estimated equal to 0.21 [17].

Additional research is needed to overcome certain limitations which remain unsolved as the fluctuations in temperatures that can significantly affect the pavement stability, or the different conductivity and density of the materials.

The simulations with KENPAVE $^{\circledR}$ and KENTRACK $^{\circledR}$ have been set at two air temperatures, 0 and $35{ }^{\circ} \mathrm{C}$, which are representatives of low and high temperatures, respectively. Consequently, two 
different temperatures within the bituminous layers were calculated as outcome of Eq. (1) using different parameters for road and railway, respectively. Afterwards, it was possible to calculate the mechanical characteristics of the bituminous materials with the Witczak-Andrei [18] predictive model based on the volumetric properties of the mixture and the characteristics of the binder (Eq. (2)):

$$
\begin{aligned}
& \log \left|E^{*}\right|=-1.249+0.029 \rho_{200}-0.002 \rho_{200}{ }^{2}-0.0028 \rho_{4}-0.058 V_{a}-0.802 \cdot\left(V_{b_{e f f}} /\left(V_{b_{e f f}}+V_{a}\right)\right)+ \\
& \left(\left(3.97-0.002 \rho_{4}+0.004 \rho_{38}-0.00002 \rho_{38}{ }^{2}+0.0055 \rho_{34}\right) /\left(1+e^{(-0.603-0.313 \log (f)-0.393 \log (\mu)}\right)\right)
\end{aligned}
$$

where:

$\left|E^{*}\right|=$ asphalt mix dynamic modulus $\left[10^{5} \mathrm{psi}\right]$;

$\rho_{200}=$ percentage of material passing to the sieve $0.075 \mathrm{~mm}$;

$\rho_{4}=$ cumulative percentage of material retained to the sieve $4.75 \mathrm{~mm}$;

$\rho_{38}=$ cumulative percentage of material retained to the $9.5 \mathrm{~mm}$ sieve;

$\rho_{34}=$ cumulative percentage of material retained to the $19 \mathrm{~mm}$ sieve;

$V_{\text {beff }}=$ effective binder content [\% by volume];

$V_{a}=$ content of air voids [\% by volume];

$F=$ load frequency $[\mathrm{Hz}]$; and

$M=$ binder viscosity $\left[10^{6}\right.$ poise $]$.

Table 4 shows the temperatures and the properties characterizing the bituminous materials.

KENPAVE $^{\circledR}$ was used to measure the stress and strain-deformations caused by the passage of ESAL at the bottom of the base course. KENTRACK ${ }^{\circledR}$ was used to simulate the stress, strain and deformation in the sub-ballast layer under the passages of different types of axles: 8, 10,12, 14, 16, 18 and 20 t. One hundred cycles have been imposed in order to avoid the cumulative damage effect.

The simulations with both softwares were carried out considering the air temperature equal to $0{ }^{\circ} \mathrm{C}$ (low temperatures representative) and $35{ }^{\circ} \mathrm{C}$ (high temperatures representative).

The horizontal tensile strains and the deflections produced in the road and railway structures were compared.

The tensile strain was selected at low temperature as the benchmark parameter for the comparison and for the definition of RESAL because it is the critical factor governing cracking and fatigue. The vertical displacement was selected as the benchmark parameter at high temperature because it is the critical factor governing rutting. The results are shown in Fig. 6 .

As it is possible to see in the graph, the values of 14.15 ton and 17.85 ton are the weights of the railway axle load that produces the same vertical displacement at high temperatures induced and the same horizontal tensile strain at low temperatures, respectively, produced by ESAL in the road structure. Thus, an average of 16 ton has been selected as the RESAL.

\begin{tabular}{|c|c|c|c|c|c|c|}
\hline \multicolumn{7}{|c|}{ Air temperature $0{ }^{\circ} \mathrm{C}$} \\
\hline & & $T$ of the layer $\left[{ }^{\circ} \mathrm{C}\right]$ & $\eta\left[10^{6}\right.$ poise $]$ & $\log \left|E^{*}\right|$ & $\left|E^{*}\right|[\mathrm{MPa}]$ & $v$ \\
\hline \multirow{3}{*}{ Road } & Wearing course & 8.30 & 11.6057 & 1.1736 & $10,282.655$ & 0.4 \\
\hline & Binder course & 8.30 & 11.6057 & 1.2081 & $11,135.245$ & 0.4 \\
\hline & Base course & 8.30 & 11.6057 & 1.2827 & $13,219.792$ & 0.4 \\
\hline Railway & Sub-ballast & 1.94 & 59.5026 & 1.4386 & $18,929.829$ & 0.4 \\
\hline \multicolumn{7}{|c|}{ Air temperature $35^{\circ} \mathrm{C}$} \\
\hline & & $T$ of the layer $\left[{ }^{\circ} \mathrm{C}\right]$ & $\eta\left[10^{6}\right.$ poise $]$ & $\log \left|E^{*}\right|$ & $\left|E^{*}\right|[\mathrm{MPa}]$ & $v$ \\
\hline \multirow{3}{*}{ Road } & Wearing course & 43.30 & 0.0014 & -0.1306 & 510.391 & 0.4 \\
\hline & Binder course & 43.30 & 0.0014 & -0.0985 & 549.562 & 0.4 \\
\hline & Base course & 43.30 & 0.0014 & -0.0453 & 621.176 & 0.4 \\
\hline Railway & Sub-ballast & 36.94 & 0.0074 & 0.2354 & $1,185.668$ & 0.4 \\
\hline
\end{tabular}

Table 4 Results of temperatures and properties obtained for road and railway layers. 


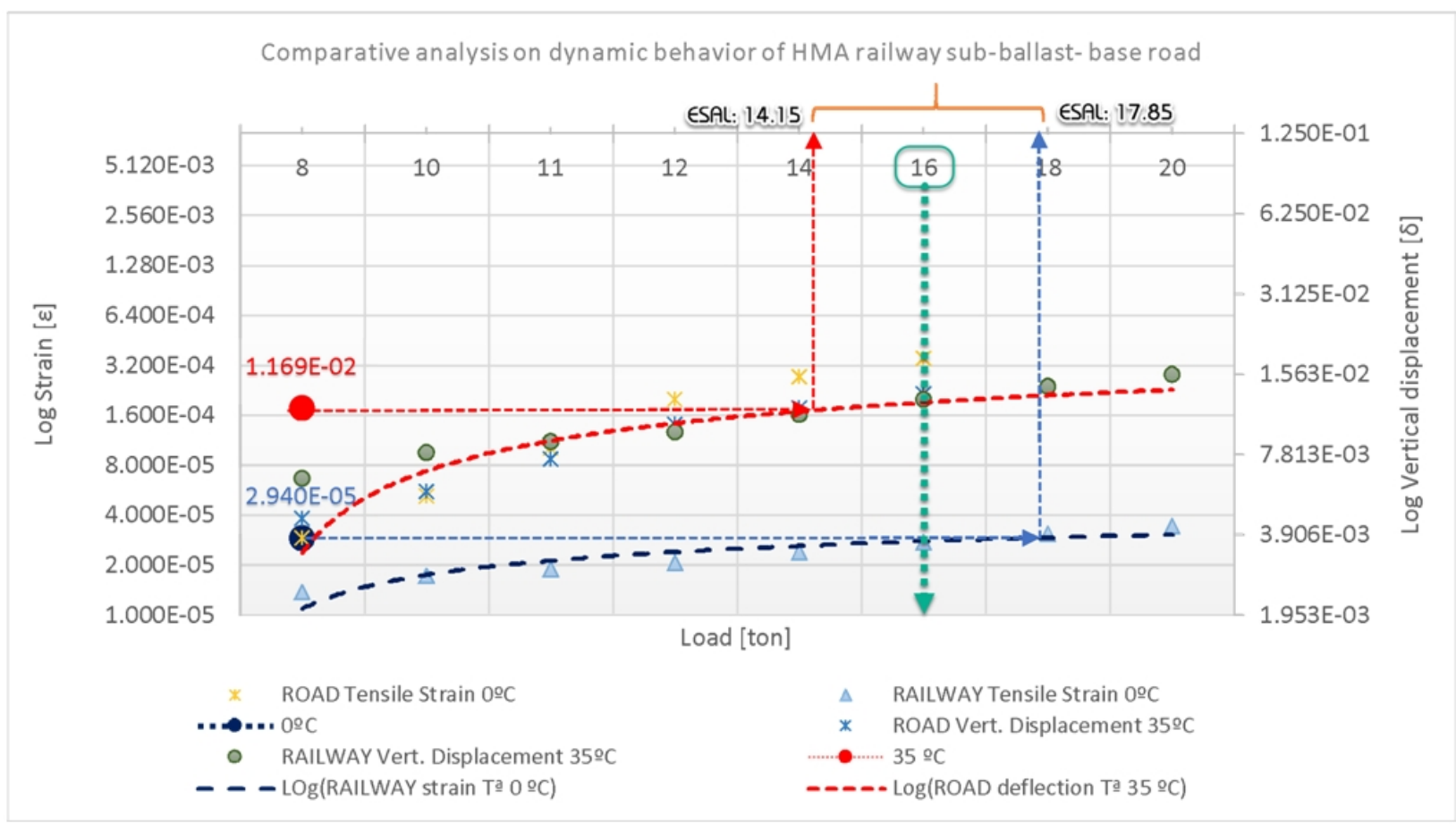

Fig. 6 Results obtained from the simulations carried out with KENPAVE ${ }^{\circledR}$ and KENTRACK ${ }^{\circledR}$.

\subsection{Conversion of the Traffic Spectrum in RESALs}

The amount of traffic is measured regarding the number of repetitions of application of loads of different axles, characteristic of the passages of vehicles on the rail-track during the service life. The traffic information to be used for the thickness design includes the magnitude of wheel loads and the number of repetitions per year. The trains considered for the case study are those operating on Italian lines.

Once the RESAL was defined equal to $16 \mathrm{t}$, the entire traffic spectrum of the railway track line was converted into numbers of RESALs to identify the traffic level and consequently the $N_{\text {design. }}$. Three different traffic lines in the Sicilian network (Messina-Catania; Siracusa-Catania, and Catania-Caltanissetta) were investigated, and their traffic spectra were converted to RESALs, using Eqs. (3)-(5):

$$
\begin{gathered}
T_{D}=365 \cdot T_{H V} \cdot\left[(1+r)^{n}-1\right] / r \\
\left.N_{D}=T_{D} \cdot \eta \cdot A \cdot R T=T_{D} \cdot\left(\sum_{j}^{m} f_{j} \cdot n_{j}\right) / \sum_{j}^{m} f_{j}\right) \cdot A \cdot R T \\
A=\sum_{k}^{m} f_{k} \cdot\left(P_{k} / P_{r}\right)^{\gamma}
\end{gathered}
$$

where:

$T_{D}=$ total number of load passages expected over the entire service life [-];

$T_{H V}=$ average daily traffic in the year of the construction [-];

$r=$ annual growth rate of traffic $(0-10 \%)[-]$;

$n=$ design life (30 years in case of sub-ballast) [year];

$N_{D}=$ RESALs at the end of the service life [-];

$N_{j}=$ number of passages of the j-axle;

$f_{j}=$ frequency of the j-axle;

$\eta=$ average number of axles for heavy wagon;

$P_{k}=k$-axle load $[\mathrm{kN}] ;$

$P_{r}=$ axle load of the reference axle $[\mathrm{kN}]$;

$\gamma=$ coefficient that depends on the material and the pavement structure. For flexible and bituminous pavement is equal to 5 ;

$R T=$ factor of transversal distribution on the rail line (rail distances $<3 \mathrm{~m} \rightarrow R T=1$ );

$f_{k}=$ frequency of passage of the $k$-axle load [-] and;

$A=$ coefficient of aggressiveness ${ }^{1}$ (e.g., road highway

\footnotetext{
${ }^{1}$ An example, for a highway outside cities, the coefficient of aggressiveness, $\mathrm{A}$, is around 1.57 . For a main rail-line the value obtained is around 0.30 , considering the different $\gamma$ coefficient respectively. According to 1993 AASHTO Guide for Flexible Pavement Structural Design.
} 
outside the city, $A=1.57$ ).

The approach to convert the railway traffic into RESALs and the correspondence road-railway are not devoid of limitations. For example, in the case of roads, the traffic load is assumed to be evenly distributed on a circular area (tire prints). Moreover, the stress distribution depends also on the tires inflation pressure [20].

Contrarily in railways, the contact area between the wheel and the rail is typically the size of a small coin. For this reason, the pressures at the interface are very high, and distributed in a different configuration [21].

The traffic level expected over a 30-year period for the three lines is summarized in Table 5 , considering the traffic growth rate equal to $0 \%, 0.2 \%, 0.4 \%, 0.6 \%$, $0.8 \%$ and $1 \%$.

The results are summarized in Fig. 7.

\subsection{Definition of $N_{\text {design }}$ as a function of Traffic- $T^{a}$}

"Volumetric mix-design method" by gyratory compactor (SGC) is the key step in developing a well-performing asphalt mixture NCHRP [10]. As the traffic level for the designed rail track increases, the design requirements increase to improve reliability. A unique feature of the mix-design is that its tests are performed at temperatures and aging conditions that more realistically represent those encountered by in-service sub-ballasts.

Once the traffic spectrum was converted into RESALs, it was possible to calculate the $N_{\text {design }}$. A logarithmic regression resulting from the interpolation of the values of Superpave [11] has been used to determine a correspondence between the number of RESALs and the number of gyrations (Fig. 8).

Table 5 Summary of the traffic levels expected on the three track-lines.

\begin{tabular}{|c|c|c|c|}
\hline \multicolumn{4}{|c|}{ RESALs at the end of the service life ( 30 years) } \\
\hline Traffic growth rate $[\%]$ & Messina-Catania & Catania-Siracusa & Catania-Caltanissetta \\
\hline 0 & $3.171 \mathrm{E}+07$ & $1.796 \mathrm{E}+07$ & $3.131 \mathrm{E}+06$ \\
\hline 0.2 & $3.265 \mathrm{E}+07$ & $1.849 \mathrm{E}+07$ & $3.223 \mathrm{E}+06$ \\
\hline 0.4 & $3.362 \mathrm{E}+07$ & $1.904 \mathrm{E}+07$ & $3.319 \mathrm{E}+06$ \\
\hline 0.6 & $3.463 \mathrm{E}+07$ & $1.961 \mathrm{E}+07$ & $3.419 \mathrm{E}+06$ \\
\hline 0.8 & $3.568 \mathrm{E}+07$ & $2.020 \mathrm{E}+07$ & $3.523 \mathrm{E}+06$ \\
\hline 1 & $3.677 \mathrm{E}+07$ & $2.082 \mathrm{E}+07$ & $3.630 \mathrm{E}+06$ \\
\hline
\end{tabular}
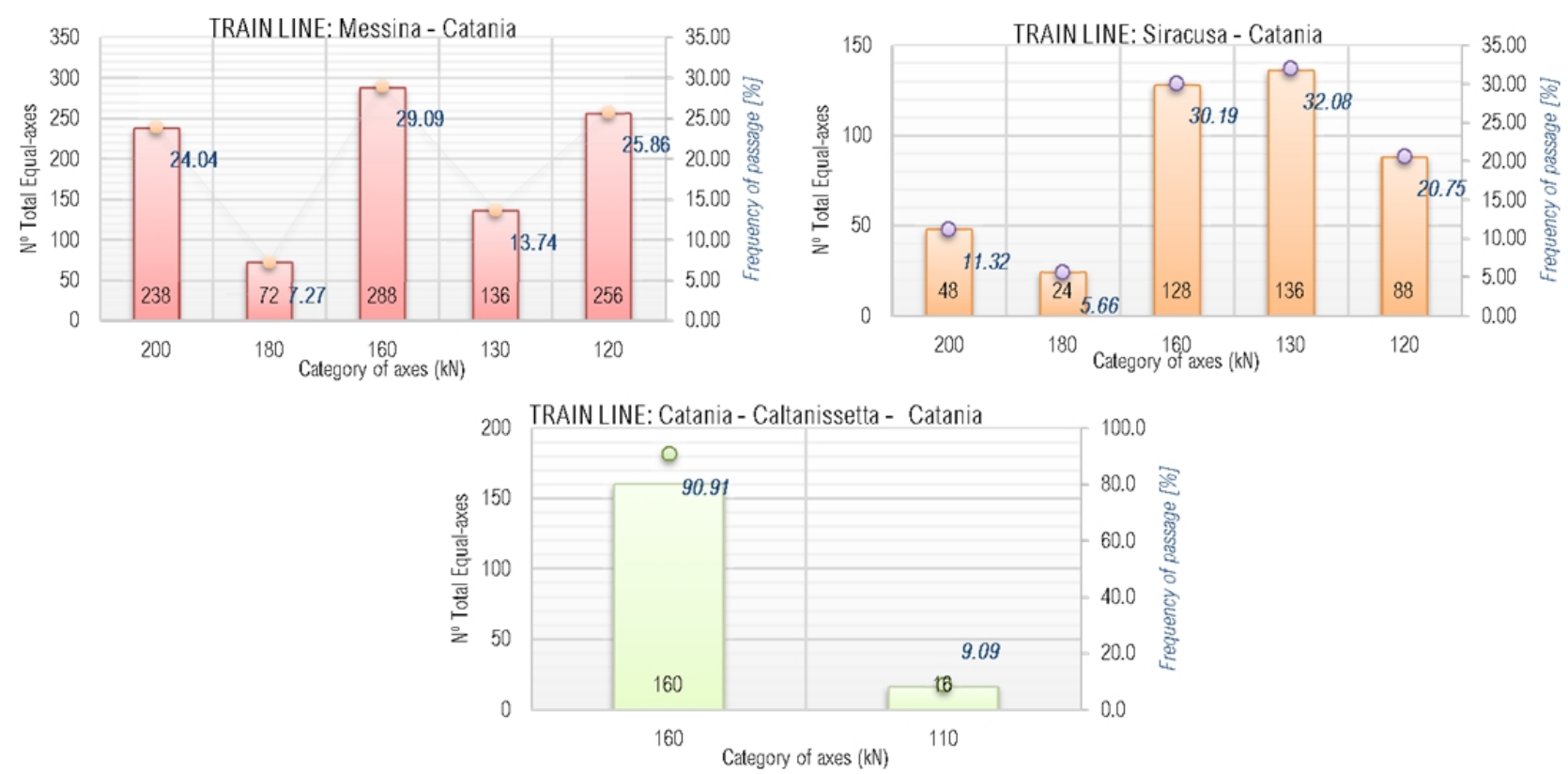

Fig. 7 Traffic spectrum of main rail-lines ( $\mathrm{N}^{\circ}$ axle/day vs. axle load, axle load vs. \%passages/day). 


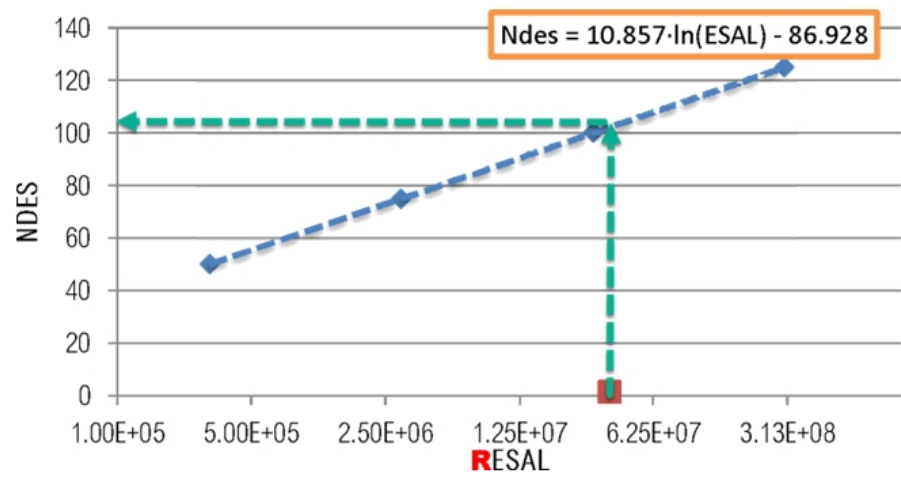

(a)

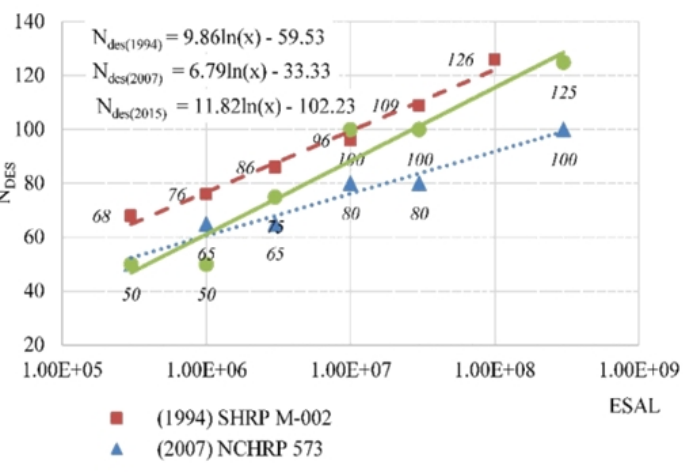

(b)

Fig. 8 (a) Logarithmic regression obtained interpolating the values of $N_{d e s i g n}$ of Superpave; (b) $N_{d e s i g n}$ recommended by "volumetric mix-design method"standards.

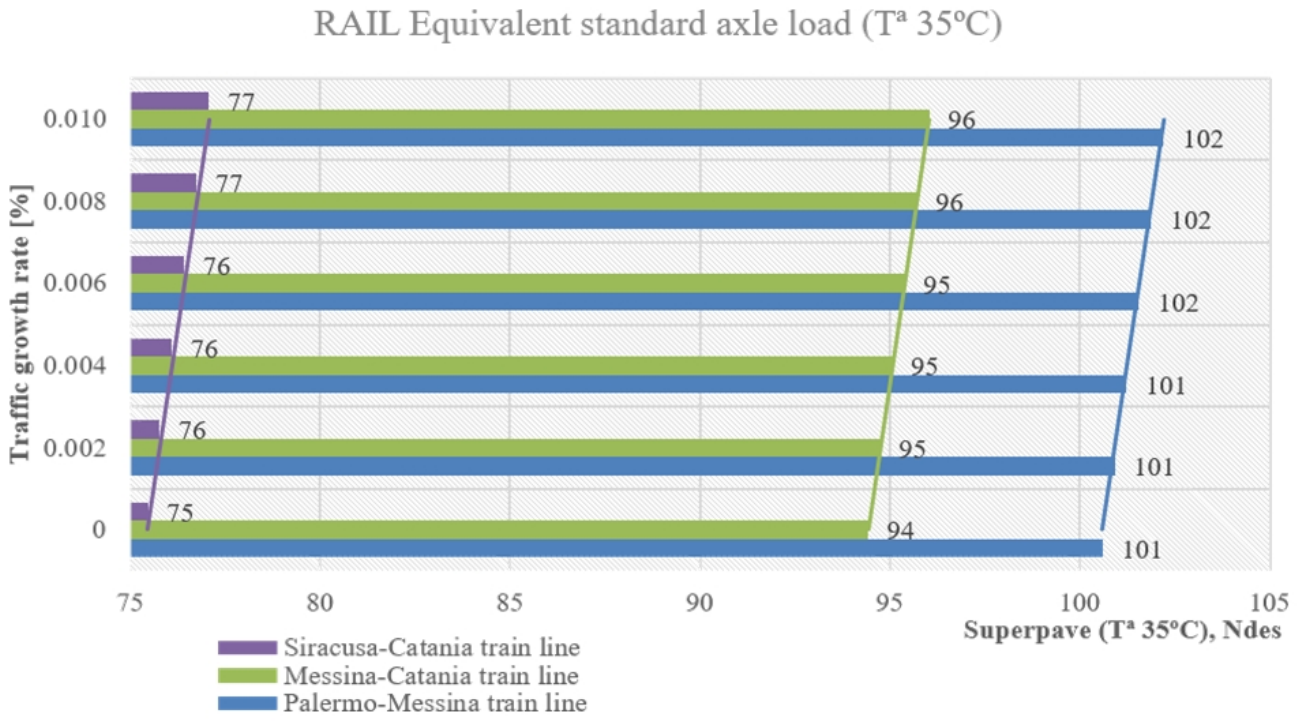

Fig. $9 N_{\text {design }}$ obtained for different track-lines and different values of annual traffic growth rate.

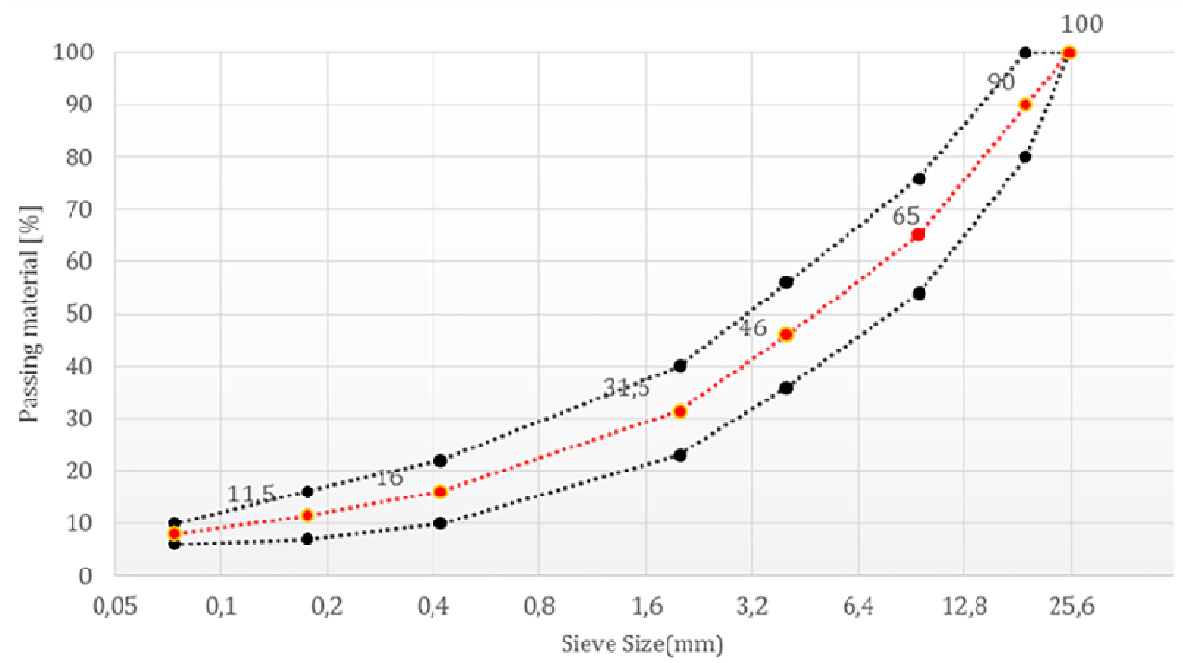

Fig. 10 Target grading curve of the bituminous sub-ballast. 
Using the logarithmic regression shown in Fig. 8a, the $N_{\text {design }}$ for the bituminous sub-ballast was calculated with each value of RESALs.

A unique correspondence between the number of gyrations and the RESALs has been defined. In Fig. 9, the number of cycles obtained for the three Italian track lines are reported, assuming different values for annual traffic growth rate.

A relationship has been established between the number of maximum ESALs determined for the rail sub-ballast of the study case and the values that in recent years have been identified for the "volumetric mix-design method". In summary, different regression curves are applied corresponding to the values of the standards and codes (Fig. 8b).

\section{Case Study}

Once the overall procedure for the mix design calculation was defined, a first laboratory verification was conducted. The methodology was applied to determine the number of gyrations in the specific case of the track line connecting Messina and Catania. The traffic growth rate was selected equal to $1 \%$. Thus, based on the results shown in Fig. 9, $N_{\text {design }}$ is equal to 102. The specifications for the bituminous sub-ballast are defined by the Italian standard (RFI) [22]. The target grading curve was selected as the medium curve between the lower and the higher limits defined by the envelope as shown in Fig. 10.

The characteristics of the materials used for the fabrication of the bituminous sub-ballast are summarized in Table 6.

Superpave mix-design of the bituminous sub-ballast was carried out setting the $N_{\text {design }}$ equal to 102 (see Fig. 9, track line Messina-Catania, annual traffic growth rate: $1 \%$ ). The compaction temperature was set at $145{ }^{\circ} \mathrm{C}$. Four different bitumen percentages $(3.6 \%$; $4.0 \% ; 4.5 \% ; 5.0 \%$ ) of the weight of aggregates were added to the mixture and compacted using the gyratory compactor. Four samples for each combination were fabricated. $3 \%$ of air voids at $N_{\text {design }}$ was selected as the target value [11].

As a further verification, the standard (RFI) requires the value of ITST (indirect tensile strength test) for the optimal recipe being higher than $0.6 \mathrm{~N} / \mathrm{mm}^{2}$. Thus, to complete a first verification of the mix design methodology proposed, an ITST at $25{ }^{\circ} \mathrm{C}$ was performed according to the standard [23].

The results of the compaction process are summarized in Fig. 11.

From the tests conducted, it emerged that the sub-ballast mixture at $N_{\text {design }}$ achieved the target voids content with $4 \%$ of bitumen in relation to the weight of aggregates. The ITS tests performed on the optimal

Table 6 Characteristics of the materials used for the bituminous sub-ballast production.

\begin{tabular}{|c|c|c|c|}
\hline \multicolumn{4}{|l|}{ Bitumen } \\
\hline Property & & Standard & Value \\
\hline Penetration at $25^{\circ} \mathrm{C}$ & & EN1426:2007 & 53 \\
\hline Penetration index [-] & & EN12591 Annex A & -0.575 \\
\hline Softening point $\left[{ }^{\circ} \mathrm{C}\right]$ & & EN1427:2007 & 50 \\
\hline Bulk gravity $\left[\mathrm{g} / \mathrm{cm}^{3}\right]$ & & EN 15326:2007 & 1.033 \\
\hline \multirow{2}{*}{ Equiviscosity T Brookfield $\left[{ }^{\circ} \mathrm{C}\right]$} & $0.28 \mathrm{~Pa} \cdot \mathrm{s}$ & EN 12695:2000 & 143.1 \\
\hline & $0.17 \mathrm{~Pa} \cdot \mathrm{s}$ & AASHTO T316-04 & 156.2 \\
\hline \multicolumn{4}{|l|}{ Aggregates (limestone) } \\
\hline Property & & Standard & Value \\
\hline Los Angeles abrasion loss [\%] & & EN 1097-2:2010 & 20.8 \\
\hline Bulk specific gravity coarse aggregates $\left[\mathrm{g} / \mathrm{cm}^{3}\right]$ & & EN 1097-3:1998 & 2.82 \\
\hline Bulk specific gravity sand $\left[\mathrm{g} / \mathrm{cm}^{3}\right]$ & & EN1097-6:2013 & 2.84 \\
\hline Bulk specific gravity filler $\left[\mathrm{g} / \mathrm{cm}^{3}\right]$ & & EN1097-7:2009 & 2.70 \\
\hline
\end{tabular}




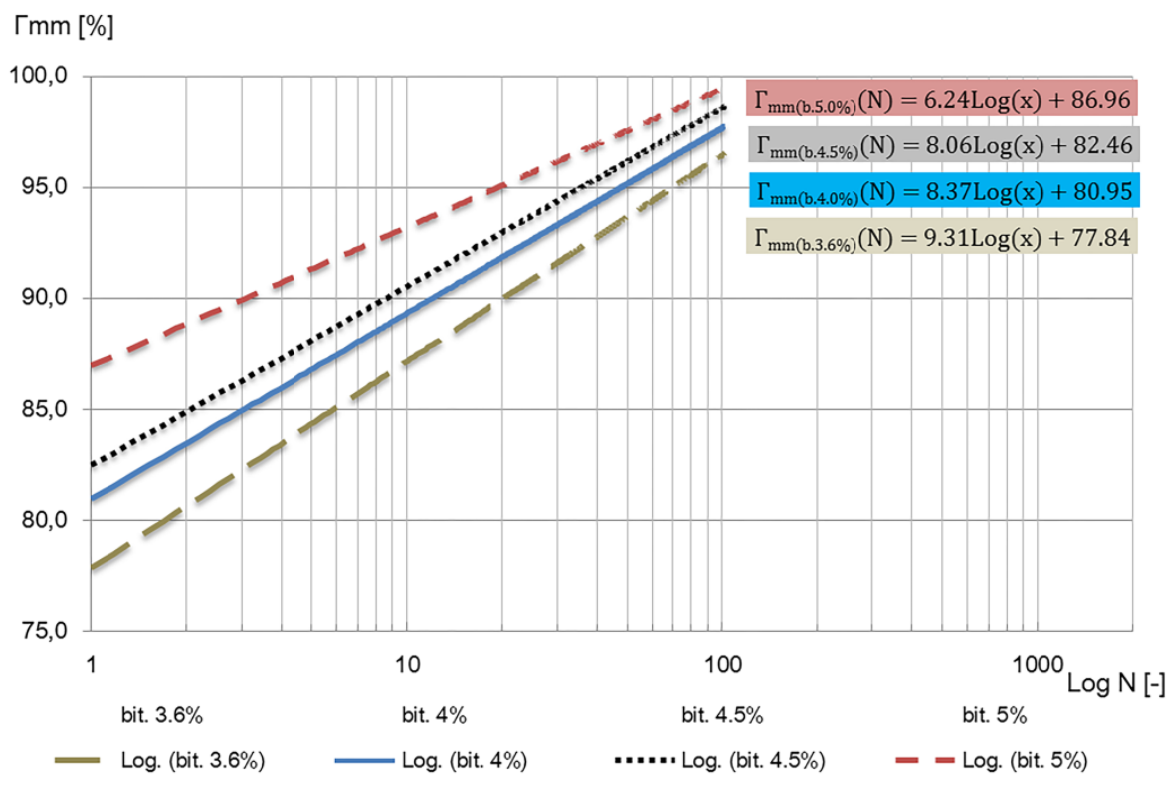

Fig. 11 Compaction curves of the bituminous sub-ballast mixtures fabricated with different binder contents.

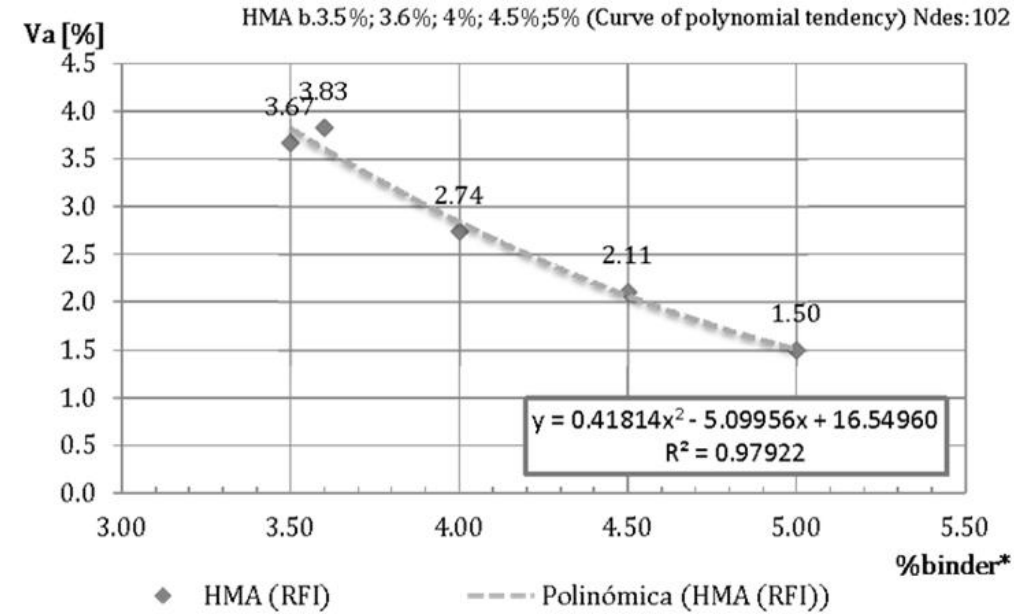

Fig. 12 Plot of percent air voids versus binder content. Optimal bitumen quantity.

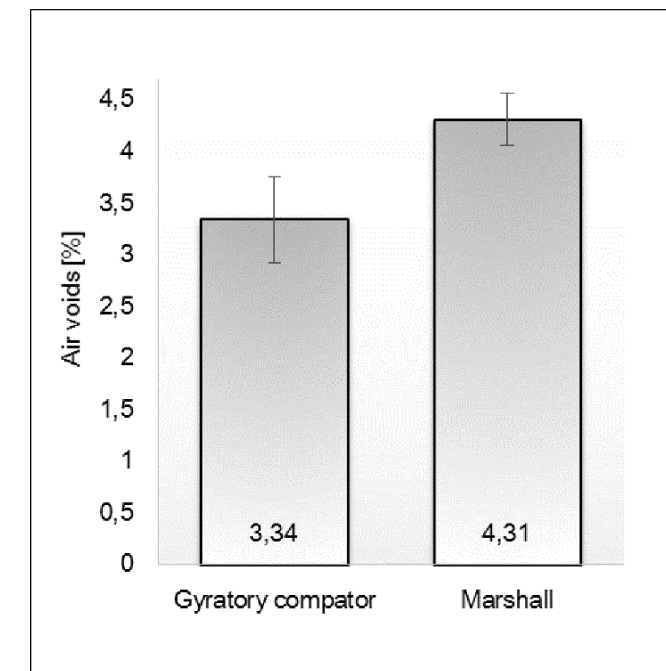

Fig. 13 Comparison of air voids contents obtained with gyratory compactor and Marshall procedure. 
recipe identified in Fig. 12 gave results higher than $0.6 \mathrm{~N} / \mathrm{mm}^{2}$ as required by standard (RFI) for the use of sub-ballast.

Fig. 13 shows the comparison between 75-blow Marshall compactive effort (4 samples) and gyratory compactor results (average of 16 samples). As shown from this plot, the air voids obtained with Marshall compaction are higher than the air voids obtained with the gyratory compactor (approximately $1 \%$ higher).

\section{Summary of Findings}

This study proposes a methodology to adapt the Superpave mix design approach, developed for the road domain, to the railway system, and in the process defining the "RESAL", i.e., rail equivalent single axle load. The benchmark parameters for the mix design approach are:

- The RESAL has been defined as the rail axle load that produces the same vertical displacement $(w)$ at high temperature $\left(35{ }^{\circ} \mathrm{C}\right)$ and the same horizontal tensile strain $\left(\varepsilon_{t}\right)$ at low temperature $\left(0{ }^{\circ} \mathrm{C}\right)$ produced by the ESAL $(80 \mathrm{kN})$ in the road structure. The tensile strain was selected at low temperature as the benchmark parameter for the comparison and for the definition of RESAL because it is the critical factor governing cracking and fatigue. The vertical displacement was selected as the benchmark parameter at high temperature because it is the critical factor governing rutting. According to this procedure, the RESAL has been defined equal to $16 \mathrm{t}$;

- A logarithmic regression resulting from the interpolation of the $N_{\text {design }}$ values of SUPERPAVE has been used to determine a unique correspondence between the number of RESALs and the number of gyrations;

- The target air voids content was established as 3\%. The sub-ballast has a structural function absorbing the loads coming from the train passages providing higher stability to the track-bed and resisting fatigue solicitations. Moreover, the bituminous sub-ballast reduces the vibrations transmitted by load passages and functions as an impermeable layer below the ballast to protect the formation from water penetration. To ensure capabilities, the target voids content was lowered from $4 \%$ of the original Superpave application to $3 \%$ with the consequent increase of bitumen content. This could result in a mixture characterized by a low permanent deformation resistance. However, rutting should not represent a concern in the track-bed because of the presence of the ballast, which allows to distribute the pressure of the axle loads over a wide area. Finally, the effect of extreme air temperatures is minimized by the presence of the upper layers.

From the study of the compactability conducted with the gyratory compactor, setting the above-mentioned parameters, it emerges that the sub-ballast mixture at $N_{\text {design }}$ achieves the target voids content with $4 \%$ of bitumen in relation to the weight of aggregates. With the optimal recipe, several samples were fabricated and compacted using gyratory compactor and the Marshall hammer. The two different compactions resulted in different contents of voids (approximately 1\% higher for Marshall compaction).

Based on the results, the methodology proposed is considered successful in estimating the optimal value of the bitumen quantity in the presented case. Nevertheless, additional work is necessary to validate the methodology using other materials and types of bituminous sub-ballast. Moreover, it is necessary to verify that the asphalt mixtures resulting from the proposed mix design methodology yield satisfactory mechanical performance. Thus, the future research program envisages to test these mixtures to evaluate the stiffness, permanent deformation and fatigue resistance.

\section{Acknowledgments}

The research presented in this presentation was carried out as part of the Marie Curie Initial Training Network (ITN) action, FP7-PEOPLE-2013-ITN. This project has received funding from the European Union's Seventh Framework Program for research, 
technological development and demonstration under grant agreement number 607524 .

\section{References}

[1] Teixeira, P. F., Ferreira, P. A., López-Pita, A., Casas, C., and Bachiller, A. 2009. "The Use of Bituminous Sub-ballast on Future High-Speed Lines in Spain: Structural Design and Economical Impact.” International Journal of Railway 2 (1): 1-7.

[2] Ferreira, T. M., Teixeira, P. F., and Cardoso, R. 2011. "Impact of Bituminous Sub-ballast on Railroad Track Deformation Considering Atmospheric Actions." Journal of Geotechnical and Geo-environmental Engineering 137 (3): 288-92.

[3] López-Pita, A., Teixeira, P. F., Casas, C., Ubalde, L., and Robusté, F. 2007. "Evolution of Track Geometric Quality in High-Speed Lines: The 10-Year Experience of the Madrid-Seville Line." In Proceedings of the Institution of Mechanical Engineers, Part F, Journal of Rail and Rapid Transit 221 (2): 147-55. ISSN 0954-4097.

[4] Sanchez, M. S., Pirozzolo, L., Moreno-Navarro, F., and Rubio-Gamez, M. 2015. "Advanced characterisation of bituminous sub-ballast for its application in railway tracks: The influence of temperature". Construction and Building Materials 101 (1): 338-46.

[5] D'Andrea, A., Loprencipe, G., and Xhixhaa, E. 2012. "Vibration Induced by Rail Traffic: Evaluation of Attenuation Properties in a Bituminous Sub-ballast Layer." Presented at SIIV 5th International Congress - Sustainability of Road Infrastructures.

[6] Di Mino, G., and Diliberto, M. 2012. "Experimental Survey on Dry Asphalt Rubber Concrete for Sub-ballast Layers." Journal of Civil Engineering and Architecture 6 (10): 1615-26.

[7] Rose, J. G., and Bryson, S. 2009. "Hot Mix Asphalt Railway Trackbeds: Trackbed Materials, Performance Evaluations, and Significant Implications." Presented at International Conference on Perpetual Pavements 2009, September 30-October 2, 2009, Columbus, Ohio.

[8] Rose, J. G., Teixeira, P. F., and Veit, P. 2011. International Design Practices, Applications, and Performances of Asphalt/Bituminous Railway Trackbeds. Paris, France: GEORAIL.

[9] Cominsky, R., Huber, G. A., Kennedy, T. W., and Anderson, M. 1994. The Superpave Mix Design Manual for New Construction and Overlays. SHRP A407. Strategic Highway Research Program National Research Council Washington, DC.

[10] NCHRP (National Cooperative Highway Research
Program). 2007. Superpave Mix Design: Verifying Gyration Levels in the Ndesign Table. Report 573.

[11] AASHTO (American Association of State Highway and Transportation Officials). 2001. Superpave Volumetric Design for Asphalt Mixtures. AASHTO R 35-151, 444 North Capitol Street N.W., Suite 249 Washington, D.C.

[12] Huang, Y. H. 1993. Pavement Analysis and Design. New Jersey, USA: Englewood Cliffs.

[13] H uang, Y. H., Lin, C., Deng, X., and Rose, J. 1984. Kentrack: A Computer Program for Hot-Mix Asphalt and Conventional Ballast Railway Trackbed. Maryland (USA): Asphalt Institute.

[14] Rose, J., Liu, S., and Souleyrette, R. R. 2014. "Kentrack 4.0: A Railway Trackbed Structural Design Program." In Proceedings of the 2014 Joint Rail Conference JRC 2014, April 2-4, 2014, Colorado Springs, Colorado, USA.

[15] Barber, E. 1957. Calculation of Maximum Pavement Temperatures from Weather Reports. Bulletin-Highway Research Board.

[16] Crispino, M., Festa, B., and Giannattasio, P. 1998. "Valutazione Delle Temperature Della Sovrastruttura Ferroviaria per alta Velocità Attraverso una Sperimentazione di Laboratorio." Presented at CIFI Congress: La Tecnologia del Trasporto su Ferro e L'Orientamento al Mercato, Napoli. (in Italian)

[17] Crispino, M. 2001. "Valutazione delle temperature in esercizio del sub-ballast ferroviario". Ingegneria Ferroviaria (2001): 1-2.

[18] Andrei, D., Witczak, M. W., and Mirza, M. W. 1999. Development of a Revised Predictive Model for the Dynamic (Complex) Modulus of Asphalt Mixtures. NCHRP 1-37A Interim Team Report, University of Maryland.

[19] LCPC-SETRA. 1997. French Design Manual for Pavement Structures Guide Technique. Ministere de l'Equipment des Transports et du Logement.

[20] Matti, H. 1995. "The Effect Of Wheel Loads On Pavements". Road Transport Technology 4: 235-41. University of Michigan Transportation Research Institute, Ann Arbor.

[21] Robinson, M., and Kapoor, A. 2009. Fatigue in Railway Infrastructure. Cambridge, UK: Woodhead publishing limited.

[22] RFI (Rete Ferroviaria Italiana). 2016. Gruppo Ferrovie dello Stato Italiane. Capitolato Costruzioni Opere Civili. Sezione XV Sub-ballast-Pavimentazioni Stradali. (in Italian)

[23] ASTM (American Society for Testing and Materials International). 2012. Standard Test Method for Indirect Tensile (IDT) Strength of Bituminous Mixtures. 

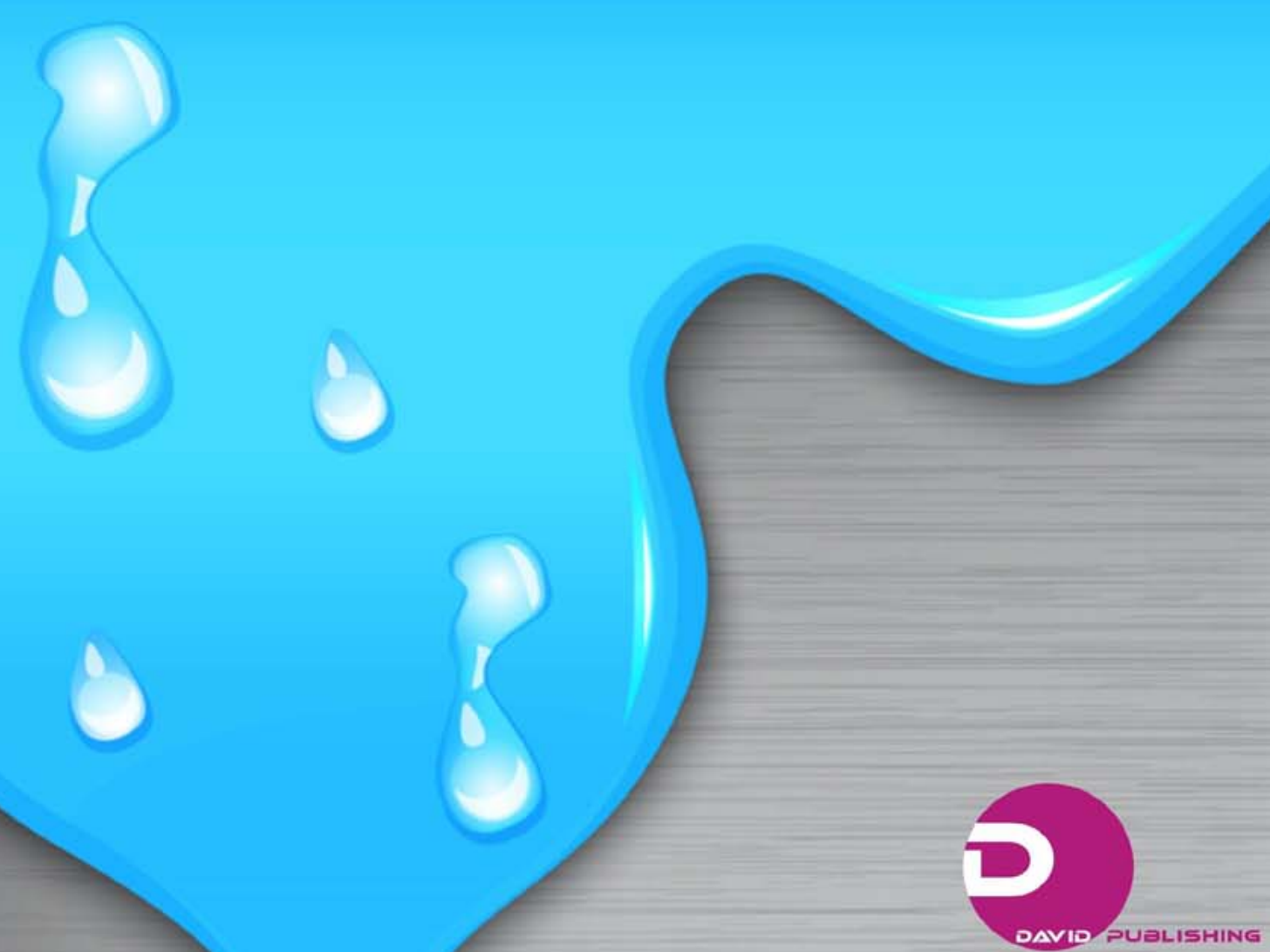

Journal of Traffic and Transportation Engineering

Volume 5, Number 5, Sep.-Oct. 2017

David Publishing Company

616 Corporate Way, Suite 2-4876, Valley Cottage, NY 10989, USA

Tel: 1-323-984-7526, 323-410-1082; Fax: 1-323-984-7374, 323-908-0457

http://www.davidpublisher.com, www.davidpublisher.org

traffic@davidpublishing.com,JTTE_davidpublishing@yahoo.com 